\title{
Cooling design and evaluation for photovoltaic cells within constrained space in a CPV/CSP hybrid solar system
}

\author{
Sheng Wang a , Junxiang Shi ${ }^{\text {a }}$, Hsiu-Hung Chen ${ }^{\text {a }}$, Steven R. Schafer ${ }^{a}$, Moiz Munir ${ }^{\text {a }}$, Greg Stecker ${ }^{\mathrm{b}}$, Wei Pan ${ }^{\mathrm{b}}$, \\ Jong-Jan Lee ${ }^{\mathrm{b}}$, Chung-Lung Chen ${ }^{\mathrm{a}^{*}}$ \\ ${ }^{a}$ Department of Mechanical \& Aerospace Engineering, University of Missouri, Columbia, MO 65211 USA \\ ${ }^{\mathrm{b}}$ Sharp Laboratories of America, Camas, WA 98607 USA
}

\begin{abstract}
A hybrid solar energy system has been designed by combining the advantages of concentrated solar power (CSP) technology and high performance concentrated photovoltaic (CPV) cells which outperforms either single technology. Thermal management is crucial to CPV cells in this hybrid solar system, as concentrated solar radiation onto the PV cells leads to higher heat flux. If the heat is not dissipated effectively, it can cause obvious temperature rise and efficiency reduction in the cell. In addition, the constrained space available for PV cell cooling in such hybrid solar systems presents more challenges. In this study both passive cooling and active cooling techniques were systematically investigated in both numerical and experimental ways. For the passive cooling method, two different designs from off-the-shelf heat pipes with radial fins or annular fins were proposed and studied under various heat rejection requirements. Results shows that heat pipes with radial fins exhibited narrow capability of dumping the heat, while heat pipes with annular fins presented better performances under the same conditions. Numerical optimal designs of annular fin numbers and fin gaps were then carried out and experimentally validated, indicating a capability of dumping moderate waste heat $(\sim 45 \mathrm{~W})$. For active cooling technique, a comprehensive study of designing plate fin heatsinks were conducted corresponding to high Ingress Protection (IP) rated off-the-shelf fans. Results show that with a less than $2 \mathrm{~W}$ fan power consumption, this active cooling method can control the average PV cell temperature below our target temperature of $75^{\circ} \mathrm{C}$ even under $45^{\circ} \mathrm{C}$ ambient. To evaluate the overall performance in a year round life cycle, the enhancement in the annual electricity output of the PV cells was estimated according to the cooling effects subjected to the climate of Tucson, Arizona. Finally, taking into consideration of both the temperature control results and net gain/loss analysis, an active cooling design was chosen for our system to dissipate a maximum waste heat of $84 \mathrm{~W}\left(21.8 \mathrm{~W} / \mathrm{cm}^{2}\right)$ due to its lower cost, lower CPV temperature, and higher net energy efficiency gain. It is also demonstrated that passive cooling will become more attractive when the heat dissipation requirement is less than $50 \mathrm{~W}\left(13.0 \mathrm{~W} / \mathrm{cm}^{2}\right)$.
\end{abstract}

Keywords: hybrid solar system; CPV/CSP; thermal management; passive cooling; active cooling

\section{Introduction}

Solar energy remains the best alternative for a truly sustainable power infrastructure which can support the human race into the foreseeable future. As such, it is effectively captured either as electricity by concentrated photovoltaic (CPV) devices or as heat by concentrated solar power (CSP). The former can be quite cost-effective, but cannot utilize the entire solar spectrum. In addition, the storage of electricity is difficult and expensive. The latter has an advantage in utilizing the full solar spectrum and has efficient thermal storage but is expensive. Knowing this, Sharp Labs of America collaborated with the University of Arizona and the University of Missouri-Columbia, and proposed building a CPV/CSP hybrid solar energy conversion system. The system aims to combine the advantages of CSP and CPV technologies in order to achieve greater exergy, better dispatchability, and a higher capacity factor at a more reasonable cost than the energy achieved by either technology alone. In this project, concentrated solar radiation is initially split into two components. One of these is directed towards an efficient heat receiver (HR1) while the other is further concentrated and directed onto a linear array of high performance PV cells (HR2) as shown in Figure 1(a). Although HR1 receives most of the thermal spectrum from the solar radiation, the reflection of the rest solar radiation to the PV cells not only leads to the photoelectric conversion but also generates additional heat in the cell which may increase the cell temperature. Under these circumstances, keeping the temperature of the PV cells below a certain threshold becomes the dominant issue. For the concentrated photovoltaic cells, higher

a* Corresponding author. Email: chencl@missouri.edu 
temperatures generally decrease the cell efficiency. Additionally, the cells will exhibit a long-term degradation and irreversible damage if a certain temperature limit is exceeded.

Cooling concentrated photovoltaic cells has received substantial attention over the last twenty years. Many investigations have been carried out experimentally and numerically to evaluate the effect of temperature on PV systems using cooling systems. An appropriate cooling design should include considerations with regards to maintaining a low and uniform cell temperature, system reliability, sufficient capacity for dealing with "worst case scenarios", and minimum power consumption by the system [1-3]. Various cooling methods that can be implemented in the CPV system, which included passive cooling (natural convection), forced air cooling, manifold/microchannel heatsinks, impingement cooling, and two-phase convective cooling [4-7]. All these methods exhibit their unique advantages in specific needs, especially for different heat dissipation requirement. Optimum cooling solutions differ among single-cell arrangements, linear concentrators, and densely packed photovoltaic cells. For single cell geometries, passive cooling is typically capable of handling the heat flux due to the large area available for heatsinking [8]. Theristis et al. [9] reported that a single cell configuration with a solar cell area of 1 $\mathrm{cm}^{2}$ can be cooled passively for concentration ratios of up to $500 \times$ with a heat sink. For linear concentrators and densely packed cells under high concentrations over 150 Suns, an active cooling system is necessary, while passive cooling is usually insufficient to handle this situation since less area is available for heatsinking. For high power concentrations, forced air cooling [10-14], jet impingement cooling [15-19], and single- or two- phase forced convection cooling with manifold/microchannel heatsinks [20-23] have been reported as adequate solutions. Many researchers are also seeking novel cooling options based on the aforementioned cooling methods, for instance, using high efficiency cell backing materials [24] and highly-conductive coatings with carbon nanotubes for passive cooling [25], and water immersed cooling [26, 27].

For regions where the water supply is abundant, using water as a coolant to reduce the temperature of solar cell is one of the best methods for improving the efficiency of a photovoltaic/thermal system since the sensible heat or even latent heat of water are way much more higher than air [28-34]. Aldossary et al. [35] compared both passive cooling and active liquid cooling for a single PV cell in harsh environment. Results show that passive cooling with two heat sinks at the back of the PV cell can only maintain its temperature below $118{ }^{\circ} \mathrm{C}$, while active cooling at low water velocity, i.e. $0.01 \mathrm{~m} / \mathrm{s}$ is able to keep the PV cell temperature at about $60{ }^{\circ} \mathrm{C}$ for the same heat load in their study. However, water itself can also be a critical issue for areas where a solar plant is built. If the region employing PV cooling has water scarcity, then it will be challenging to use this wet cooling method. On the other hand, the water cooling system is more complex and power consuming than the air-cooled system.

With regards to the linear configuration of the PV cells implemented in our system, a simple, low cost cooling design is highly desirable especially in a constrained space. The system tracks the sun as it passes from east to west (in trough-level). In addition, to keep the focal spots centered on the PV cells and reduce spot enlargement caused by off-axis aberrations, the linear array of Fresnel lenses and PV cells tracks from north to south (in celllevel). The constrained space (twelve cell cards installed side-by-side shown in Figure 1(b)) in cell-level tracking limits the design options for cooling underneath each cell card (Figure 1(c)) as collision from improper heat exchangers may occur when cell cards rotate during tracking. Considering the environmental condition of Tucson Arizona, we simply evaluate and optimize our designs based on dry cooling methods. In this work, two cooling options, passive cooling and active forced convection cooling, were systematically studied. In general, long-term sustainability, lower maintenance costs, and zero input power required for passive cooling make it a very attractive option for relatively low heat dissipation requirement, while active cooling presents obvious advantage of temperature control for high solar concentration. However, the extra power consumption and regular maintenance cost can still make it a to-be-decided option. Therefore, it is indispensable to evaluate the overall gain or loss of both cooling methods with the different solar radiation ratios. 


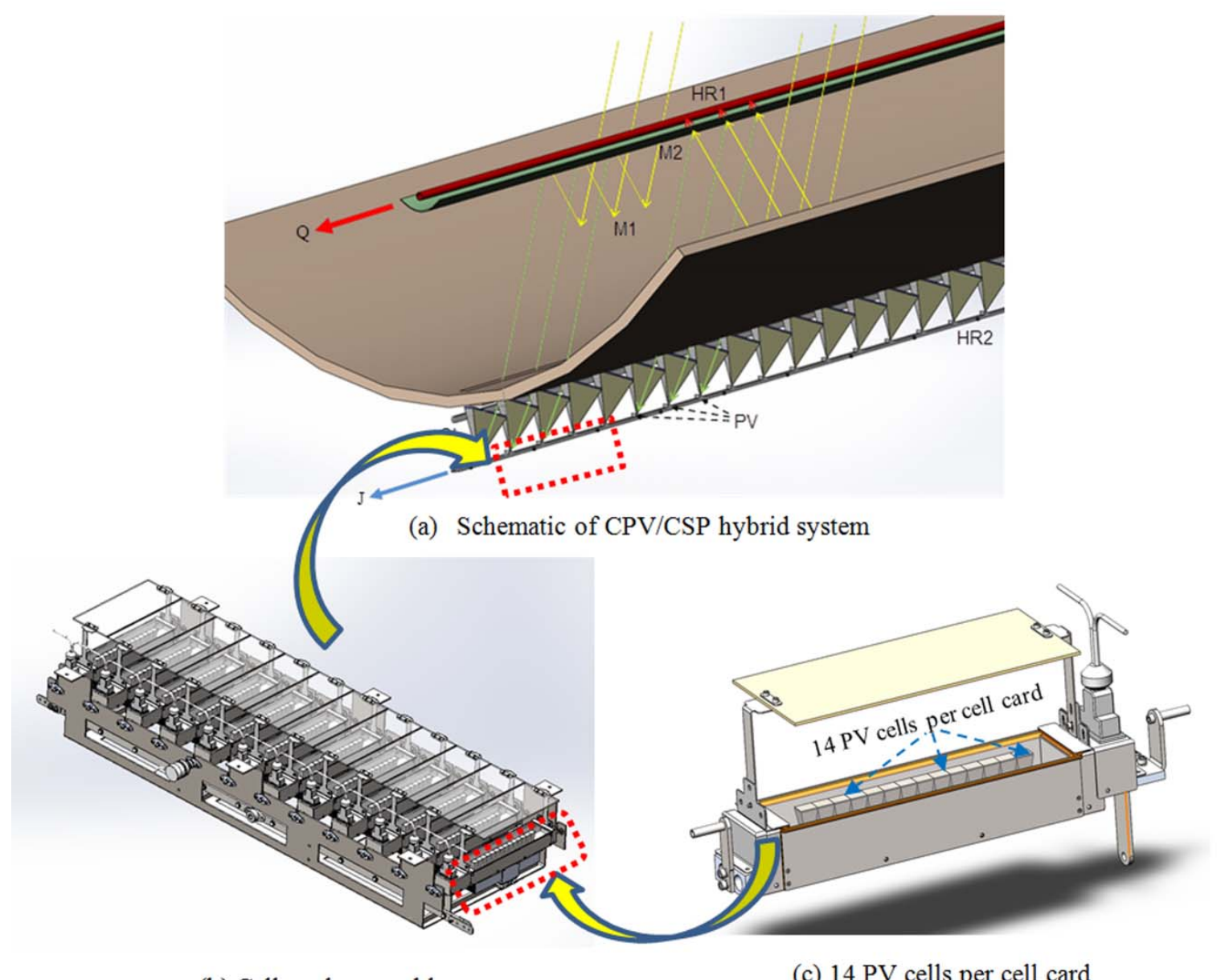

(b) Cell cards assembly

(c) 14 PV cells per cell card

Fig. 1. Schematic of CPV/CSP hybrid system and PV cell card unit and trough assembly

\section{Cooling options description}

In our design of the CPV/CSP hybrid solar energy conversion system, the PV cells will operate at a relatively low temperature and the associated thermal losses will not be collected, but simply dissipated to the environment. Two kinds of dichroic mirror (M1 shown in Figure 1 (a)) were proposed to be used in the integrated our CPV/CSP hybrid solar energy conversion system, leading to two different heat loads (a maximum heat load of about $64 \mathrm{~W}$ for Design I, and $84 \mathrm{~W}$ for Design II) on PV cells resulting from different split ratios of the solar radiation. Figure 2 shows the waste heat per cell card, collected based on the temperatures during the 20th day of each month in Tucson, AZ.

According to the heat removal requirement, our target is to maintain an operating temperature below $80{ }^{\circ} \mathrm{C}$ on each PV cell. With regards to different dichroic mirror designs, the maximum waste heat generated in the $14 \mathrm{PV}$ cells per cell card is about $84 \mathrm{~W}\left(21.8 \mathrm{~W} / \mathrm{cm}^{2}\right)$; each PV cell is $5.0 \mathrm{~mm} \times 5.5 \mathrm{~mm}$, leading to a maximum heat flux of $21.8 \mathrm{~W} / \mathrm{cm}^{2}$. Epoxy is generally used as a thermal interfacial material between the PV cells and cell card. The thermal conductivity of the epoxy layer is about 4 to $8 \mathrm{~W} / \mathrm{mK}$, while the thickness of the layer is typically about 0.08 to $0.15 \mathrm{~mm}$. When the heat flux is $21.8 \mathrm{~W} / \mathrm{cm}^{2}$, the temperature difference across a single PV cell is approximately 2 to $8{ }^{\circ} \mathrm{C}$. Therefore, the temperature on the cell card should be lower than $75^{\circ} \mathrm{C}$, assuming an average temperature difference of $5{ }^{\circ} \mathrm{C}$ across the thermal interfacial layer. To avoid confusion, $75{ }^{\circ} \mathrm{C}$ is used as the target in the following sections. 

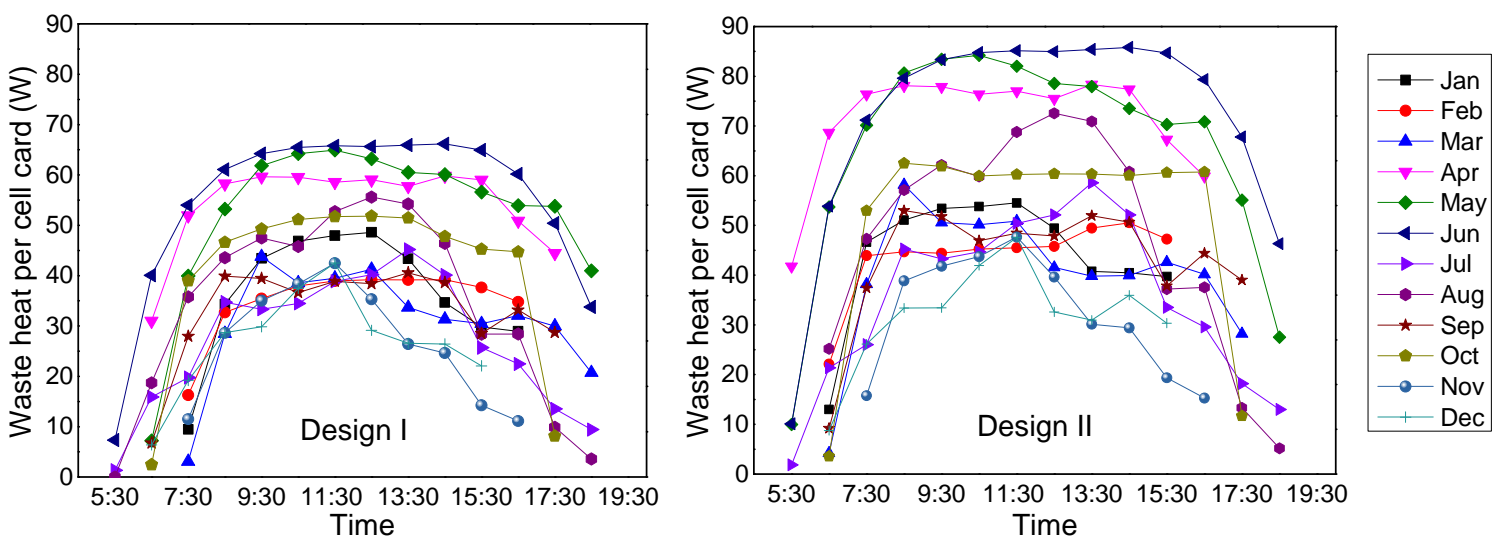

Fig. 2. Waste heat on the 20th day of each month in Tucson, AZ for two different dichroic mirror designs

The schematic in Figure 1 shows a linearly installed cell card trough assembly (b) and details for one cell card (c). In this configuration the cell cards are mounted in one line and have less area available for heatsinking because two sides on each cell card are in close contact with neighboring cell cards. The areas available for heat sinking can only extend from two of the sides and the back of the cell card. Thus, the cooling design option should be strictly related to the size of the cell card. However, the space underneath the cell card is also limited due to the height of the trough design. Therefore, the space constraint becomes the most critical consideration for the cooling design.

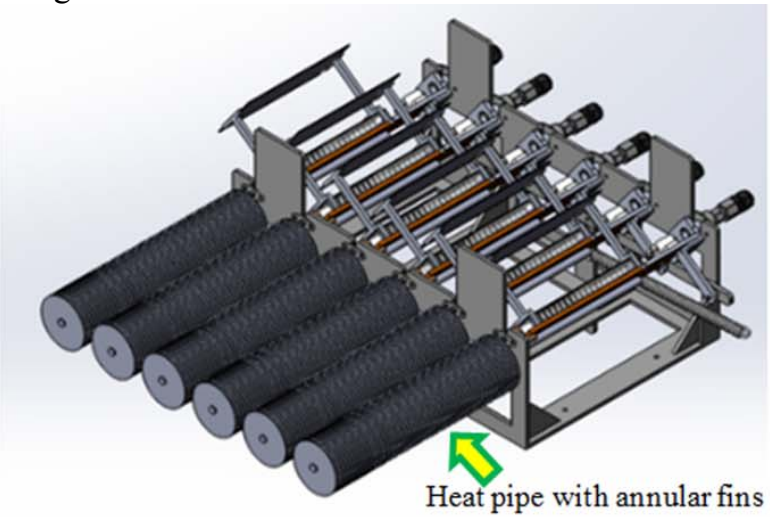

(a) Passive cooling

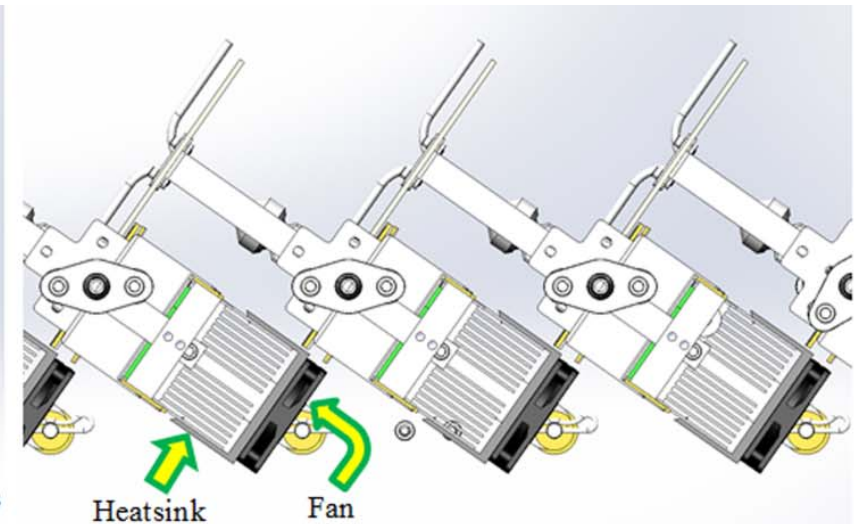

(b) Active cooling

Fig. 3. Schematic of two cooling design options; (a) passive heat pipe cooling; (b) active fan cooling

To dissipate the required waste heat for this system we proposed several active and passive cooling methods. Figure 3 shows both a passive (a) and active (b) cooling design. In order to have a large heat transfer area in the passive design we combined extended heat pipes with either annular or radial fins. For active cooling, it is common to place a heatsink underneath the cell card. A low power consumption fan will be used to drive the air flow through the heatsink to dissipate the required heat load. An ambient temperature of $35{ }^{\circ} \mathrm{C}$ is used to evaluate the heat dissipation performance for the different designs. Since the integrated system will be demonstrated in Tucson, Arizona, where the peak ambient temperature can sometimes reach $45^{\circ} \mathrm{C}$, we also studied the worst case scenario of maintaining the cell card at a temperature lower than $75^{\circ} \mathrm{C}$ in a $45^{\circ} \mathrm{C}$ environment. When comparing the passive and active cooling methods, the highest monthly average temperatures during a whole year in Tucson, $\mathrm{AZ}$ were used as the ambient temperatures. Based on these two methods, a comprehensive investigation has been conducted numerically and experimentally in order to find out which is able to achieve the best cooling performance. 


\section{Numerical and experimental study}

Running full-scale simulations or experiments of the full solar configuration is prohibitively costly (either monetarily or computationally) since one trough may contain tens of concentrating lenses and PV cell units. Instead, a single PV card unit may be analyzed. So long as care is taken in setting up the representative experiments the results will be indicative of each unit in the full trough configuration, and the overall performance of the larger system can be determined.

\subsection{Modeling description}

The modeling work was used to estimate the performance of each cooling method before fabricating a prototype. ANSYS CFX/ICEPAK/Thermal Analysis 14.5 was used to numerically model each cooling configuration.

\subsection{Experimental setup and uncertainty analysis}

Our experimental setup on either the passive or active cooling option is based on the same heat removal condition. A heating block, carrying cartridge heaters and heating fingers, is fastened to a copper structural frame with a clamp, shown in Figure 4. The heat, generated from the cartridge heaters, will flow down the heating fingers. The heat flux can be determined through monitoring the temperature difference collected by thermocouples embedded in each of the heating fingers. In order to monitor the heat flux flowing through each of the heating fingers to the cold block, 28 thermocouples were used. Each heating finger has 2 thermocouple ports to help collect $\Delta \mathrm{T}$. The bottoms of the heating fingers touch the PV substrate. The cross section of each heating finger is machined to be $5.0 \mathrm{~mm}$ by $5.5 \mathrm{~mm}$, which is the same size as the PV cell. The temperatures of the PV cells are estimated from the measured heat flux and the thermocouple closest to the cold block using a one-dimension thermal conduction model. Thermal insulation material (R13) is used to simulate the adiabatic boundary condition. Power input is controlled by a variac power supply. Four cartridge heaters are used to provide the heat load; each cartridge heater can generate a maximum of $32 \mathrm{~W}$ at $120 \mathrm{~V}$. A data acquisition (DAQ) system is used to continuously monitor the temperatures. This DAQ (USB-2416 with AI-EXP32, Measurement Computing, Norton MA), collects temperature readings from 32 different channels at a rate of 1000 samples per second. The thermal test takes about 3 hours to reach steady-state, or about 1 hour to reach $90 \%$ of the steady-state condition. Each test, therefore, took at least 3 and half hours to complete. We then averaged the steady-state temperature data from the last 30 minutes of each test for post processing.

The overall uncertainty for the predicted tip-end temperature was calculated based on the method described by Moffat [36, 37], determined from the measured temperatures and estimated heat flux. The Type-T, class-1 thermocouples used for all temperature measurement have the accuracy uncertainty of $\pm 0.5^{\circ} \mathrm{C}\left(-40\right.$ to $\left.125^{\circ} \mathrm{C}\right)$. The uncertainty caused by mechanical machining is $\pm 0.0125 \mathrm{~mm}$. In addition, the thermocouple positioning error was estimated to be $\pm 0.25 \mathrm{~mm}$ ( $1 / 2$ of the thermocouple AWG Gage of 24). The relative uncertainty in the estimated tipend temperature of each heating finger was determined to be no larger than $\pm 1.3 \%$ at $84 \mathrm{~W}$.

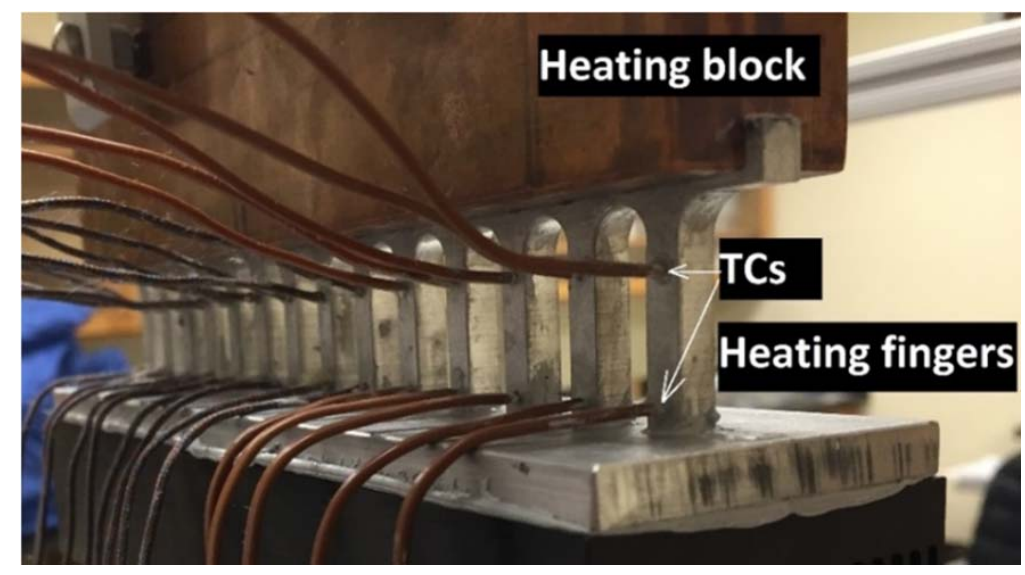

Fig. 4. Test-bed simulating heat rejection from each PV cell 


\subsubsection{Passive heat pipe cooling}

A schematic showing a profile view of the passive cooling method is displayed in Figure 5 (a). A single passive cooling setup (Figure 5(b)) includes two heat pipes (Enertron-Inc.), 40 annular-fins, and one cell card. The heat pipes are $12 \mathrm{~mm}$ in diameter. The annular-fin heatsink is composed of copper discs (copper alloy 110), 76.2 $\mathrm{mm}$ in diameter and $1.23 \mathrm{~mm}$ in thickness. The adiabatic boundary condition, shown in red dotted lines, is enforced by placing thermal insulation material on both sides. On the other hand, another set of experiments was also designed with no side insulation materials in order to see the effect of this insulation setup, shown in Figure 5(c).

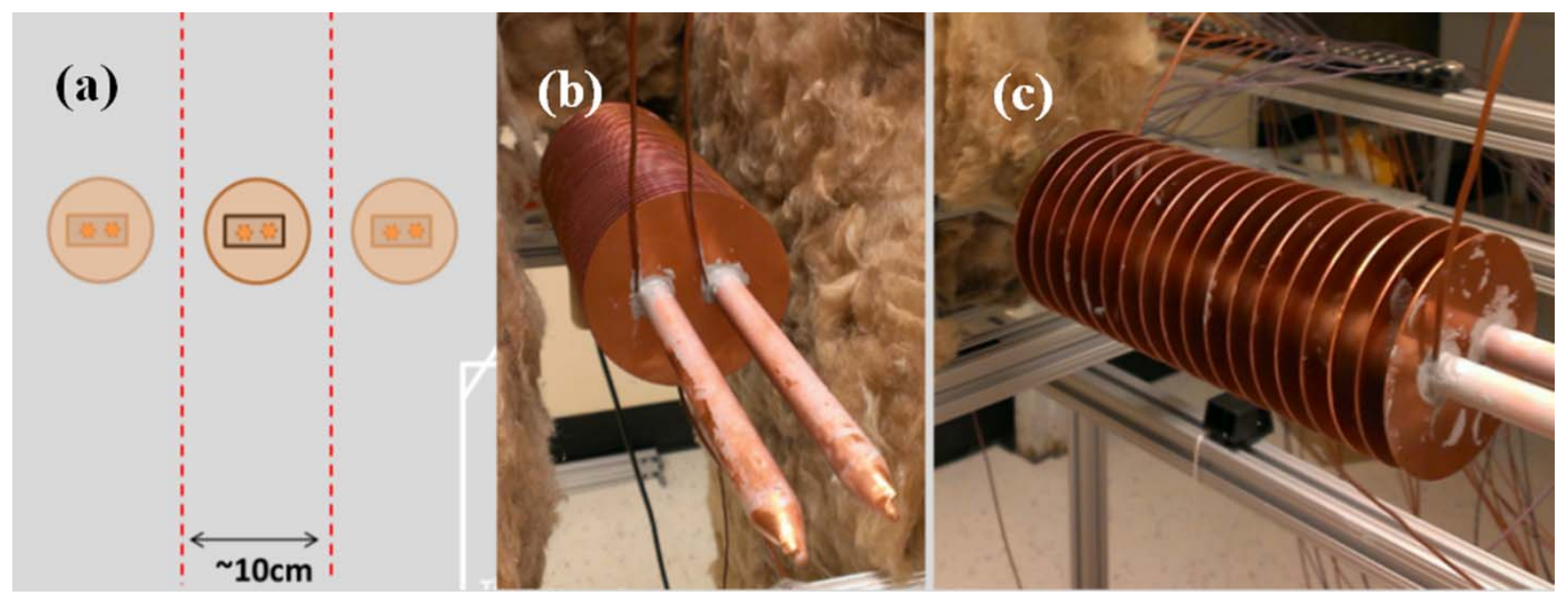

Fig. 5. Two-straight-heat-pipe design for the passive cooling option. (a) Schematic of the experimental setup in sideview. Dotted red lines represent the adiabatic boundaries. Thermal insulation is $\sim 10 \mathrm{~cm}$ apart (inner-wall to innerwall). (b) Isometric view of the experimental setup. 40 annular fins are used in this experiment. Heat pipes are 25.4 $\mathrm{mm}$ apart (center to center). (c) Another isometric view of an 18-fin experiment with no wall-insulation.

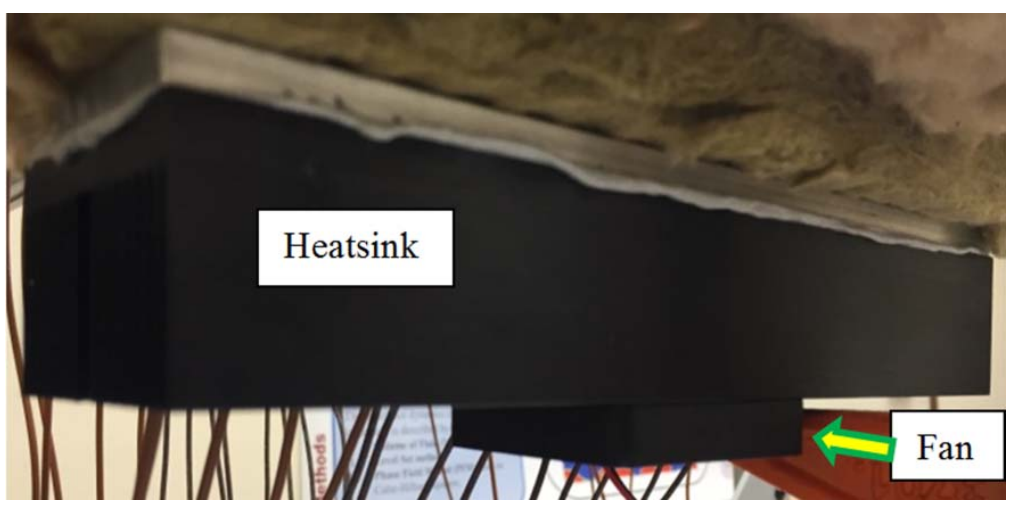

Fig. 6. Photo of fan-heatsink design for active cooling option

\subsubsection{Active fan cooling}

Figure 6 shows an image of the fan-heatsink design for the active cooling option. A low power consumption DC fan is used to drive the air flow through a plate fin heatsink to remove the required heat load. Pin fins may perform better than plate fins in some cases. However, ease of manufacturing was a major consideration when determining the fin design, and as such only parallel plate-fins were studied. The power consumption of the fan is also an important factor in the active cooling design. Due to a $2 \%$ usage limit of the average output electricity of about $105 \mathrm{~W}$ for each cell card in our system, the fan power will be limited to about $2.1 \mathrm{~W}$ per cell card. In order to find the most cost-effective solution we tried different fan-heatsink combinations to dissipate the waste heat. Meanwhile, different fan installation locations were tested during the experiments.

\subsection{Validation between modeling and experiment}


In the modeling work, thermal contact resistance between parts was not considered. This may partially account for the discrepancy between the numerical and experimental results. The thermal conductivity of the thermal grease used in the experiments is $2.3 \mathrm{~W} / \mathrm{mK}$ (Omegatherm 201), with a thickness of about $50 \sim 100 \mu \mathrm{m}$. Assuming a one-dimensional thermal conduction problem, for active cooling with a $84 \mathrm{~W}$ heat load, the resulting temperature difference between the thermal grease layer is about 3 to $6{ }^{\circ} \mathrm{C}\left(4.5^{\circ} \mathrm{C}\right.$ in average $)$. For passive cooling with a $45 \mathrm{~W}$ heat load, the resulting temperature difference is about 2 to $4{ }^{\circ} \mathrm{C}\left(3^{\circ} \mathrm{C}\right.$ in average $)$ due to the multiple contact interfaces. After considering $3^{\circ} \mathrm{C}$ contribution from contact resistance, the modeling results were verified by the experimental measurements (the numerical result shown in Figure 8 vs. the case of double heat pipe at $45.1 \mathrm{~W}$ in Table 1) with a relative deviation within $16 \%$ for passive cooling $\left(\sim 63{ }^{\circ} \mathrm{C}\right.$ vs. $\left.73{ }^{\circ} \mathrm{C}\right)$. For active cooling with an 84 $\mathrm{W}$ heat load with the consideration of $4.5^{\circ} \mathrm{C}$ contribution from contact resistance, the modeling results were verified by the experimental measurements (the numerical result shown on the upper-left of Figure 14 vs. case 4 with Delta 5020 at $84.6 \mathrm{~W}$ in Table 3$)$ with a relative deviation less than $5 \%\left(\sim 67{ }^{\circ} \mathrm{C}\right.$ vs. $\left.63.9^{\circ} \mathrm{C}\right)$ under the same fan power. The numerical results were used to estimate the performance at different heat loads in order to optimize the design.

\section{Performance evaluation}

\subsection{Passive heat pipe cooling}

For the passive cooling option, we experimentally tested three different designs. The heat transfer performance of different combinations of single or double heat pipe configurations with either radial fins or annular fins was evaluated. For the first case, we used one radial-fin heatsink (19755-XXL-AB, Wakefield) and one heat pipe $(\Phi=12.7 \mathrm{~mm}$, Advanced Cooling Technologies, Inc.). Due to the structural constraint, the heat pipe was carefully bent to $90^{\circ}$, shown in Figure 7 (a), so that the radial-fin heatsink and the heat pipe could be utilized in a more favorable orientation. Figure 7 (b) shows the design of two radial-fin heatsinks with two heat pipes. Both heat pipes were also carefully bent to $90^{\circ}$ and installed into the cooling block. The gap between the heat pipes and the corresponding through-holes drilled in the radial-fin heatsink is about $0.4 \mathrm{~mm}$. Thermal grease was applied at the gap area to reduce the corresponding thermal interface resistance.
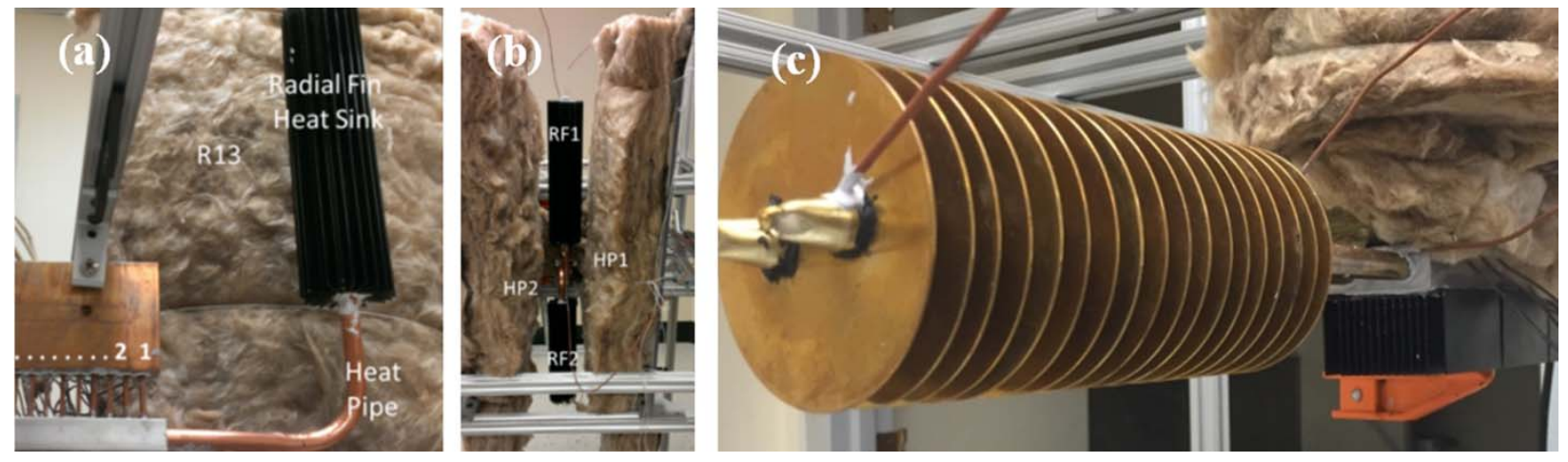

Fig. 7. Photo of the passive cooling option; (a) Single heat pipe with radial fins; (b) Double heat pipe with radial fins; (c) double heat pipe with annular fins

\subsubsection{Design of heat pipe with radial fin}

For the single heat pipe with radial fins, we did not perform any numerical effort as the bent heat pipes had unpredictable thermal parameters to provide for the modeling. We therefore tested two cases in experiments, with and without insulation materials demonstrating the real PV cell card array and one single set of the cooling device only, respectively. A summary of the experimental results, regarding the tip end temperatures of the heating fingers under different heat loads when the ambient was offset, can be found in Table 1. For the single heat pipe configuration, which dissipated about $43 \mathrm{~W}$, the estimated average temperature at each heating finger under the covered condition is $85.6^{\circ} \mathrm{C}$. The maximum is $89.1^{\circ} \mathrm{C}$. In the uncovered case with the same heat load, the average tip-end temperature is $82.8{ }^{\circ} \mathrm{C}$, and the highest is $86.7^{\circ} \mathrm{C}$, which is about 2.4 to $2.8^{\circ} \mathrm{C}$ lower than that in the covered case. Since our goal is to cool the PV cells within a target temperature of $75^{\circ} \mathrm{C}$ under heat loads which can be much higher than $43 \mathrm{~W}$, it is obvious that the single heat pipe with radial fins is incapable of removing the required heat. Therefore, a dual heat pipe design is proposed while only uncovered cases were studied under different heat loads 
for simplicity. We conducted a series of experiments with 2 heat pipes and 2 radial-fin heatsinks under four different heat loads: $38.7 \mathrm{~W}, 43.0 \mathrm{~W}, 45.1 \mathrm{~W}$, and $50.3 \mathrm{~W}$. The results shown in Table 1 illustrate the heat rejection capability of this design. When the heat load is $43.0 \mathrm{~W}$, the highest temperature is $74.9^{\circ} \mathrm{C}$, which almost reaches the $75^{\circ} \mathrm{C}$ threshold. With a heat load of $45.1 \mathrm{~W}$, the average temperature is $73.0^{\circ} \mathrm{C}$ which is below $75{ }^{\circ} \mathrm{C}$, however, the maximum temperature exceeds the $75{ }^{\circ} \mathrm{C}$ limit. For a heat load of $50.3 \mathrm{~W}$, the average temperature is higher than $75^{\circ} \mathrm{C}$. It seems the design with two heat pipes and two radial-fin heatsinks can bring most of the PV cells within the target temperature range of $75^{\circ} \mathrm{C}$ or below, under a heat load of $43 \mathrm{~W}$. When the heat load is beyond $50 \mathrm{~W}$, the two heat pipes with radial-fin heatsinks are not able to satisfy the thermal requirement. One can expect to increase the heat rejection capacity by enlarging the heat transfer area with annular fins or installing a plate-fin heatsink underneath the cell card, which was then our main focus for the passive cooling option, shown in Figure 7 (c).

\section{Table 1}

Tip end temperature for heat pipe and radial fin design (ambient is off-set to $35^{\circ} \mathrm{C}$ ).

\begin{tabular}{ccccc}
\hline Passive design & $\begin{array}{c}\text { Insulation } \\
\text { conditions }\end{array}$ & Heat load $(\mathbf{W})$ & $\begin{array}{c}\text { Average tip end } \\
\text { temperature }\left({ }^{\circ} \mathbf{C}\right)\end{array}$ & $\begin{array}{c}\text { Maximum tip end } \\
\text { temperature }\left({ }^{\circ} \mathbf{C}\right)\end{array}$ \\
\hline $\begin{array}{c}\text { Single Heat Pipe } \\
\text { with Radial Fin }\end{array}$ & Covered Case & 43.0 & 85.6 & 89.1 \\
& Uncovered Case & 43.1 & 82.8 & 86.7 \\
\hline $\begin{array}{c}\text { Double Heat Pipes } \\
\text { with Radial Fins }\end{array}$ & Uncovered Case & 38.7 & 67.6 & 71.1 \\
& & 43.0 & 70.9 & 74.9 \\
& & 50.3 & 73.0 & 77.1 \\
\hline
\end{tabular}

\subsubsection{Design of heat pipe with annular fins}

The temperature profile for the double heat pipe with annular fins design was numerically investigated and then experimentally verified. In the passive cooling simulation, radiation was simulated using a surface-to-surface model. The emissivity of the annular fins was assumed to be 0.2 , corresponding to copper with a thin oxide layer. A Laminar flow model was used, as the Rayleigh number based on the annular fin dimensions is smaller than 108. Since there were dozens of annular fins, it was time-consuming to perform a simulation of the whole domain. Therefore, a single annular fin with symmetric boundary layer conditions was used to estimate the average heat transfer coefficient. ANSYS thermal module was employed to estimate the performance of the passive cooling configuration. Parametric studies on fin diameter, thickness, and pitch size were performed to determine the optimal design. The results were used to guide the design parameters, such as the length of the heat pipe, the dimensions of the radial fin and the number of the radial fins. Except for the emissivity, there is another uncertain variable in the simulation: the effective thermal conductivity of the heat pipe. In this work, an empirical formulation [38] was used to estimate its effective thermal conductivity. Figure 8 (a) shows the overall temperature distribution of an 18 fin design, while the heat load is $45.1 \mathrm{~W}$ for 14 cells. The highest temperature observed is about $63.7^{\circ} \mathrm{C}$, which is much better than the radial fin design. Figure 8 (b) shows the temperature distribution on 14 PV cells. All 14 temperatures vary within $1{ }^{\circ} \mathrm{C}$.

During the experimental test for the passive cooling option, we used two heat pipes ( $460 \mathrm{~mm}$ in length, 12 $\mathrm{mm}$ in diameter) bonded with copper fins (using Omegabond 200 epoxy) and a spacer at one tip for later installation. Meanwhile, we combined the dual heat pipes with a parallel plate-fin heatsink attached to the cell card (also shown in Figure 7 (c)). In order to find a more economical solution (lower fin area with comparable heat rejection capability), we kept the condensation section the same $(\sim 170 \mathrm{~mm})$, and changed the distance between two adjacent fins in 3 experiments: fin-to-fin spacing of $4.2 \mathrm{~mm}$ ( 31 fins in total), $5.6 \mathrm{~mm}$ ( 26 fins in total), and $8.4 \mathrm{~mm}$ (18 fins in total). Figure 9 (a) shows the tip temperature estimated from the measured temperature at each heating finger. Heating finger \#1 is the closest finger to the annular-fin heatsink (condenser). An increasing temperature trend (low at lower numbered fingers) holds; however, since the clamping force, which is used to attach the heating fingers to the cold block, is applied close to the center, the lowest temperature occurs at the center. Other factors, including the 
surface finish of the heating finger and the cold block, etc., may also affect the temperature at the tip. Based on these three tests, it is obvious that the fin configuration with $8.4 \mathrm{~mm}$ spacing will cost less and weigh less (48\% less) while providing a fair heat rejection capability when compared to the other configurations.

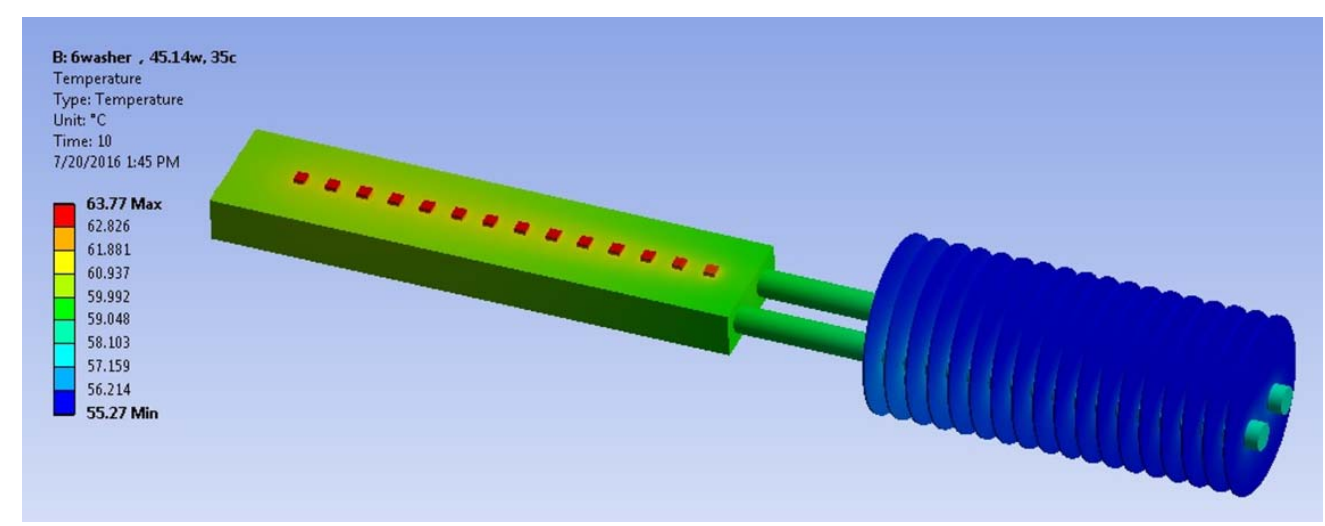

(a) Overall temperature distribution

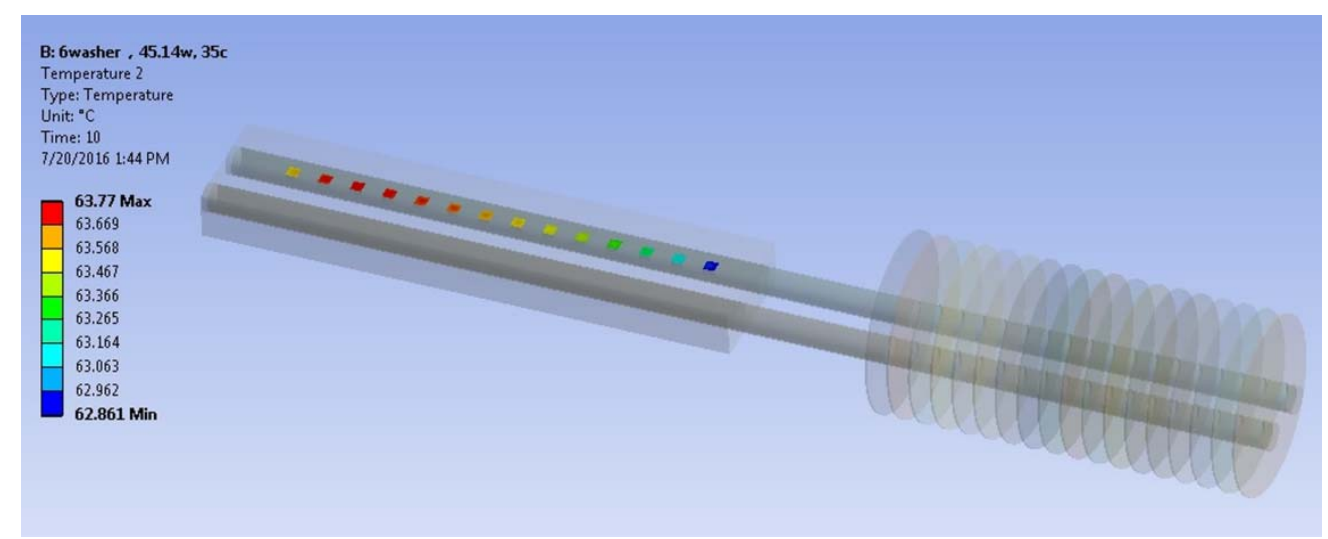

(b) Temperature distribution on PV cells

Fig. 8. Numerical results passive cooling with 18 fins under a heat load of $45.1 \mathrm{~W}$ at $35^{\circ} \mathrm{C}$ ambient, (a) overall temperature distribution; (b) temperature distribution on PV cells
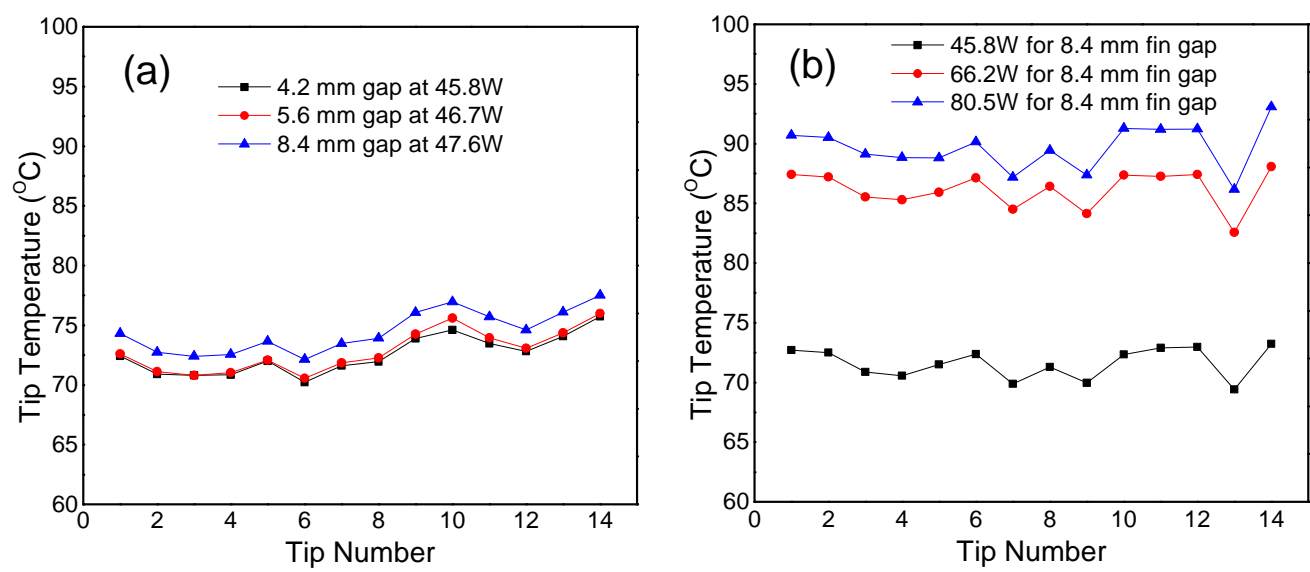

Fig. 9. Temperature estimated for each tip ends under different fin gap conditions and different heat loads. (a) Three fin-gap conditions; (b) different heat load for $8.4 \mathrm{~mm}$ fin gap condition; (Ambient temperature is off-set to $35^{\circ} \mathrm{C}$ ) 
Based on the 18 fin configuration, Figure 9 (b) shows the tip end temperatures under three different heat loads while the ambient temperature is offset to $35^{\circ} \mathrm{C}$. It is clear that for the case with $45.8 \mathrm{~W}$, the overall tip end temperature can be maintained at less than $75^{\circ} \mathrm{C}$. But in the case of $66.2 \mathrm{~W}$ or $80.5 \mathrm{~W}$, the average temperatures are higher than $85{ }^{\circ} \mathrm{C}$ which is higher than our target temperature of $75{ }^{\circ} \mathrm{C}$. Thus, it can also be expected that this passive heat pipe cooling design with annular fins will also be challenging when dissipating heat loads larger than $50 \mathrm{~W}$.
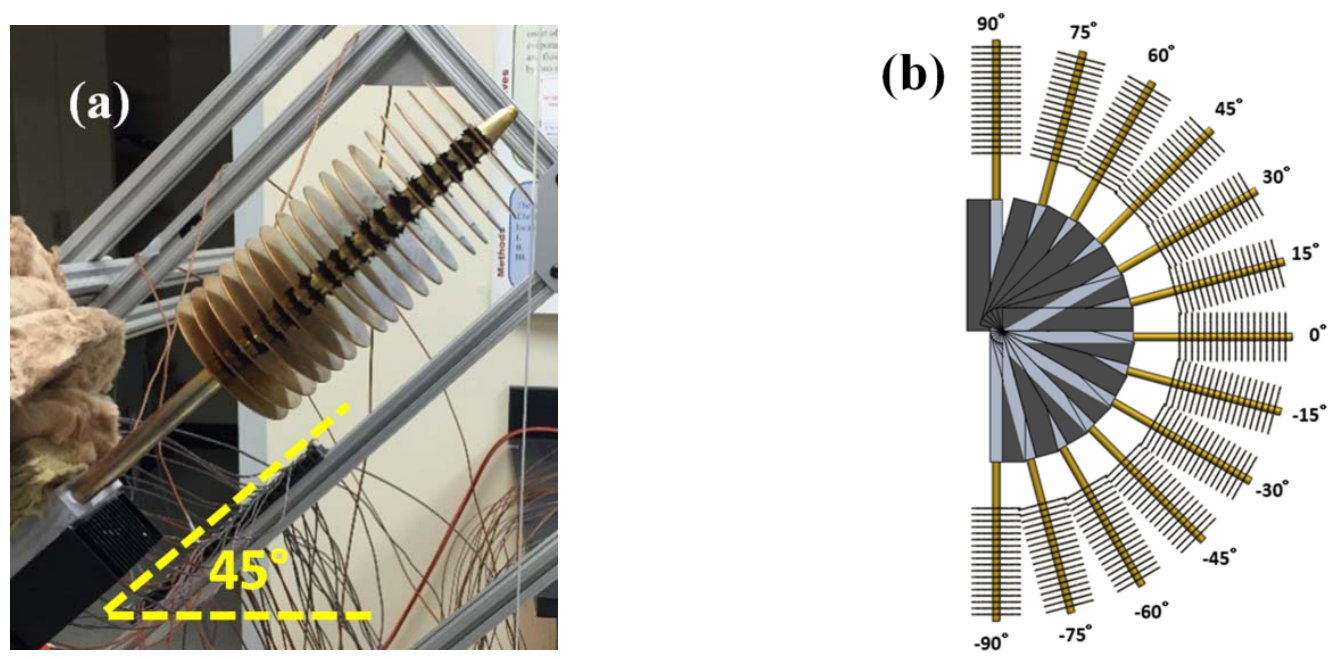

Fig. 10. Different rotation angles for double heat pipe with annular fin design. (a) Photo of $45^{\circ}$ upward direction; (b) Schematic diagram of the different rotation angles from $-90^{\circ}$ to $90^{\circ}$.

Due to practical use, we also considered the influence of seasonal effects while trough rotates during the year. Also, the performance of the heat pipe is strongly influenced by gravitational effects. When the heat pipe rotates with the trough, the performance of the heat pipe will increase in one direction and decrease in the other direction. Meanwhile, the natural convective heat transfer is also affected by the direction of the radial fins. Experimental tests for the passive cooling design based on the year-round temperature variation in Tucson, Arizona were conducted, especially for the maximum heat load conditions occurring in June during the year. A complete set of experiments were carried out to collect all the necessary data to estimate its annual performance. From the waste heat data shown in Figure 6, we can see that the system works from early morning until late afternoon. Thus, we can match the rotation angle of the testing device with the daily-based heat load. Figure 10 (a) shows the heat pipe position when the frame structure is rotated $45^{\circ}$ upward. The entire rotation process is shown in Figure 10 (b). All 13 different rotation angles were tested from $-90^{\circ}$ to $90^{\circ}$, while we defined facing straight upward as $90^{\circ}$, and facing straight downward as $-90^{\circ}$.
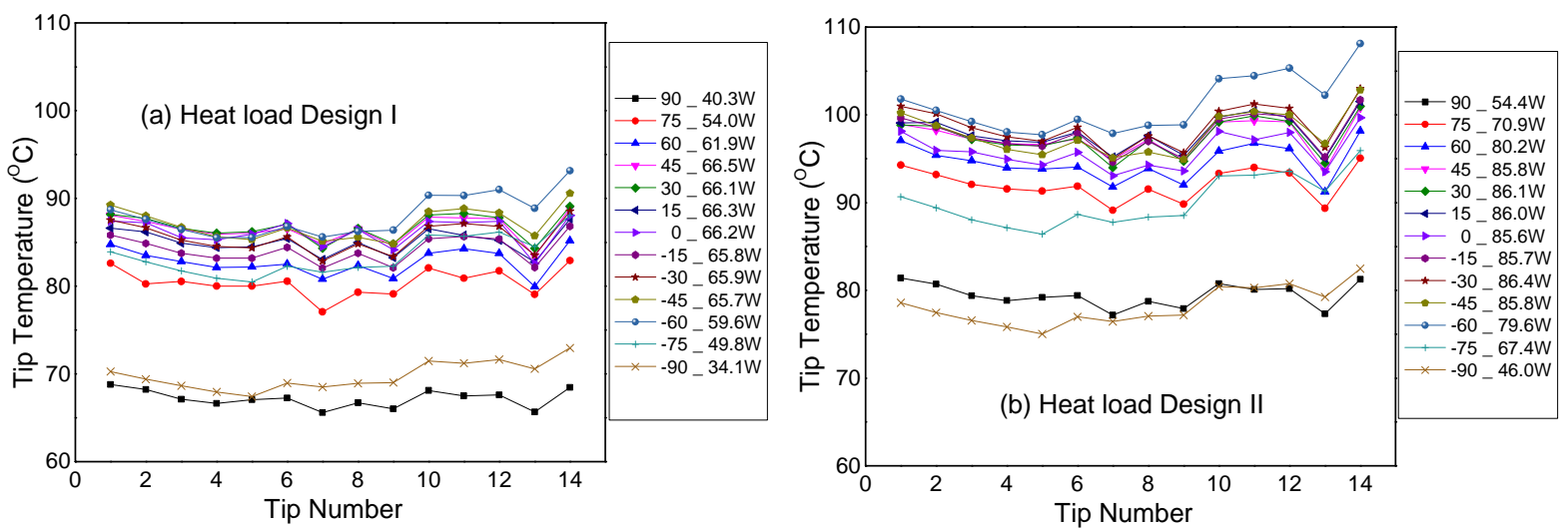

Fig. 11. Tip end temperature distribution at different rotation angles based on a maximum daily (June 20th) heat load. (a) Design I; (b) Design II. (Ambient temperature is off-set to $35^{\circ} \mathrm{C}$ ) 
Figure 11 shows the experimental results of the tip end temperature distribution at different rotation angles based on a maximum daily (June 20th) heat load test for both Designs I and II. Results show that passive the cooling method can effectively maintain a tip end temperature below $75^{\circ} \mathrm{C}$ for most cases while the waste heat is below 50 $\mathrm{W}$. A waste heat above $50 \mathrm{~W}$ presents a substantial challenge in maintaining the temperature below the limit. The average tip end temperature under maximum heat load conditions would be over $95{ }^{\circ} \mathrm{C}$. The worst performance occurs when the heat pipe is facing $60^{\circ}$ downward and the heat load is $79.6 \mathrm{~W}$. The average tip end temperature would be higher than $101{ }^{\circ} \mathrm{C}$ while the maximum reaches almost $110{ }^{\circ} \mathrm{C}$. It is quite obvious that with the passive cooling method, the average tip end temperature could be much higher than $75{ }^{\circ} \mathrm{C}$ under a $35{ }^{\circ} \mathrm{C}$ ambient. This is especially true for Design II, where average tip end temperature approaches $100{ }^{\circ} \mathrm{C}$. Therefore, it will be a great challenge for this passive cooling design to meet the high heat load rejection requirements for either Design I or Design II.

\subsection{Active fan cooling}

\subsubsection{Performance of different sized fans}

Since both of the aforementioned passive cooling methods are incapable of meeting the temperature control requirement, we then focused on a forced air cooling method, expecting to dissipate more heat with the higher air flow speed. Different fan and heatsink combinations were tested in order to find the least expensive route towards fulfilling our heat rejection requirement. Two different fan configurations were selected for our first stage testing: (1) two cell cards sharing one big fan, FAN14025 (EVERCOOL, 140x140x25 mm, $3.36 \mathrm{~W}$ in power consumption); (2) one cell card with one fan, FAN6010 (EVERCOOL, 60*60*10 mm, $1.92 \mathrm{~W}$ in power consumption). Different fan installation locations were tested, and the results are shown in Figure 12. For FAN14025, we have tested case 1, 2 and 3 with different rotation angles. For case 4 and 5, we have tested FAN6010 installed at the center or side underneath the heatsink. The configurations present in these test cases are outlined in Table 2.

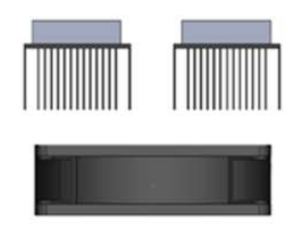

Case 1 : upward

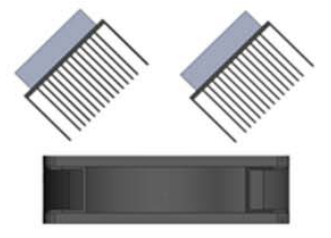

Case 2: 45 degree inward Case 3: 45 degree outward
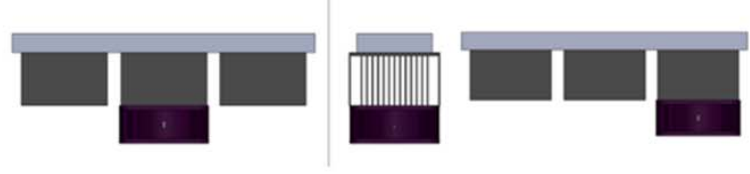

Case 4: Center underneath

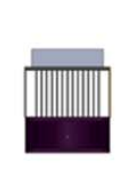

Case 5: Side underneath

Fig. 12. Five different installation locations with FAN14025 and FAN6010

Table 2

Summary of temperature results estimated for each different fan cooling option.

\begin{tabular}{clcccc}
\hline \multirow{2}{*}{ Fan type } & \multicolumn{1}{c}{ Fan-heatsink assembly } & $\begin{array}{c}\text { Heat } \\
\text { load } \\
\text { (W) }\end{array}$ & $\begin{array}{c}\text { Power } \\
\text { consumption } \\
(\mathbf{W})\end{array}$ & $\begin{array}{c}\text { Average tip end } \\
\text { temperature } \\
\left({ }^{\circ} \mathrm{C}\right)\end{array}$ & $\begin{array}{c}\text { Maximum tip } \\
\text { end temperature } \\
\left({ }^{\circ} \mathbf{C}\right)\end{array}$ \\
\hline \multirow{2}{*}{$\begin{array}{c}\text { Fan } \\
14025\end{array}$} & Case 1: one fan-two cell card horizontal & 81.19 & 1.68 & 63.8 & 67.7 \\
\cline { 2 - 6 } & Case 2: one fan-two cell card 45 inside & 82.23 & 1.68 & 66.4 & 69.5 \\
\cline { 2 - 6 } & Case 3: one fan-two cell card 45 outside & 80.50 & 1.68 & 75.4 & 78.1 \\
\hline \multirow{2}{*}{ Fan 6010 } & Case 4: one fan-one cell card (Center) & 81.49 & 1.92 & 67.5 & 71.0 \\
\cline { 2 - 6 } & Case 5: one fan-one cell card (Side) & 79.93 & 1.92 & 69.4 & 74.3 \\
\hline
\end{tabular}


Figure 13 summarizes the experimental results with different fan cooling designs under a heat load of about $80 \mathrm{~W}$. Of the three different directions towards the heatsink tested for FAN14025, facing upward keeps the tip end temperature much lower than the other two, which is quite reasonable as it gives the largest wind blowing area. The real challenge occurs when the cell card rotates outwards, creating the smallest wind blowing area between the fan and heatsink. The detailed results in Table 2 show that the average tip end temperature is $75.4{ }^{\circ} \mathrm{C}$; however the maximum may reach up to $78.1^{\circ} \mathrm{C}$, which makes the temperature distribution unacceptable during certain daily operating periods. Except for this case, the tip end temperature remains much lower than $75{ }^{\circ} \mathrm{C}$. Better average temperature performance is achieved with FAN6010. Two different fan installation positions were investigated: the bottom-center case and the side case. For both cases, all the tip temperatures were below $75{ }^{\circ} \mathrm{C}$. However, it is clear that a fan installed at the center would lead to both lower average temperatures and peak temperatures. The results indicated that the capability of rejecting a waste heat of $80 \mathrm{~W}$ by active fan cooling is quite achievable. Using only a single large fan with two cell cards would still be challenging at certain times during the day since the cell block rotates outwards and there is less wind blowing area between the fan and heatsink. For the small fan option, one small fan installed at the center of the cell card is seen to be a better choice.

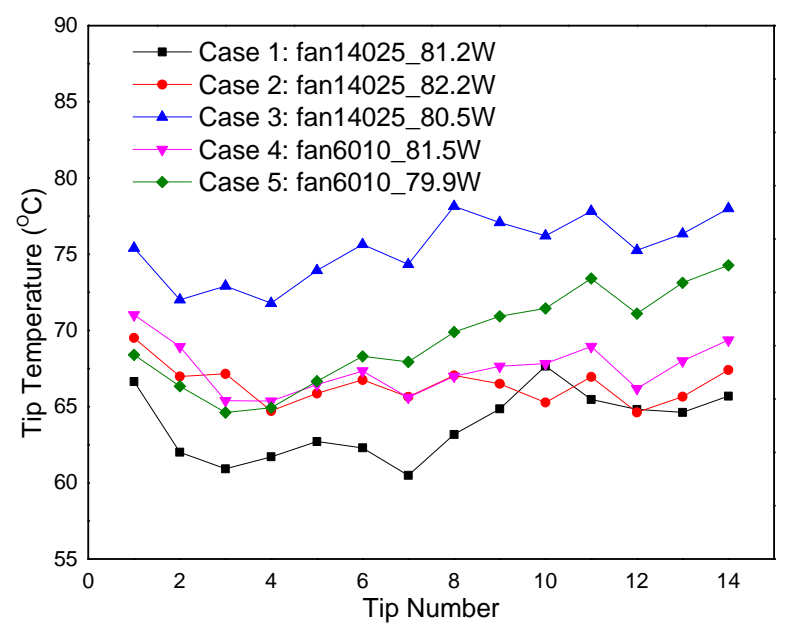

Fig. 13. Temperatures estimated for each tip end for different fan cooling options. (Ambient temperature is off-set to $\left.35^{\circ} \mathrm{C}\right)$

\subsubsection{Performance of different fan installation locations}
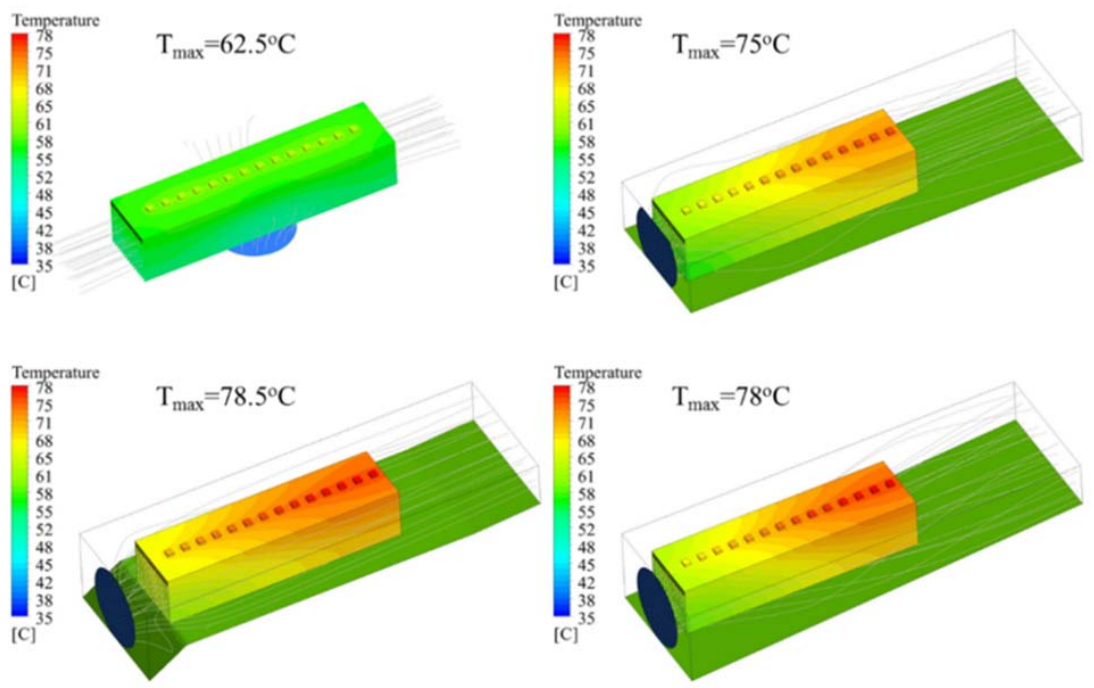

Fig. 14. Temperature distribution for the forced air cooling method with different fan locations 
Since FAN6010 performed well when installed under the heatsink, we further looked into other possible installation locations for this fan option. In the active cooling simulation, a fan curve describing the relationship between mass flow rate and pressure head is input in the model. Gravity effects and radiation are neglected. The SST k- $\omega$ turbulence model is used as the Reynolds number through the heat sink exceeded 5000 . The average grid number for each case is $\sim 2$ million. The grids with 1 million and 3.5 million elements are used to verify the grid independence. A $2 \%$ deviation is found between the cases of 2 million and 3.5 million elements. The locations of the fans vs. thermal performance were studied, and Figure 14 shows four designs. The round blue (in either light or dark) surface denotes the fan position and the rectangular green surface denotes the guided wall. The guided wall is used to streamline the air flow and force it in the heatsink channels. Here the heat load is $84 \mathrm{~W}$. The fan model is FAN6010. It is apparent that the fan underneath the heatsink outperforms others, as it gives a much lower maximum temperature due to a more uniform air flow distribution.

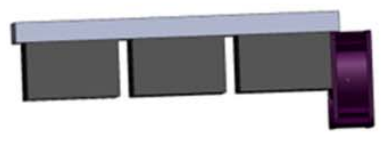

Case 6

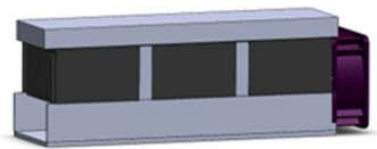

Case 7

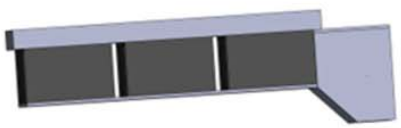

Case 8

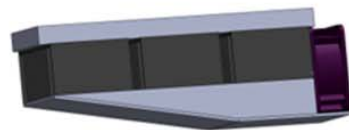

Case 9

Fig. 15. Schematic diagrams of 8 installation locations with FAN6010 for side-blowing method

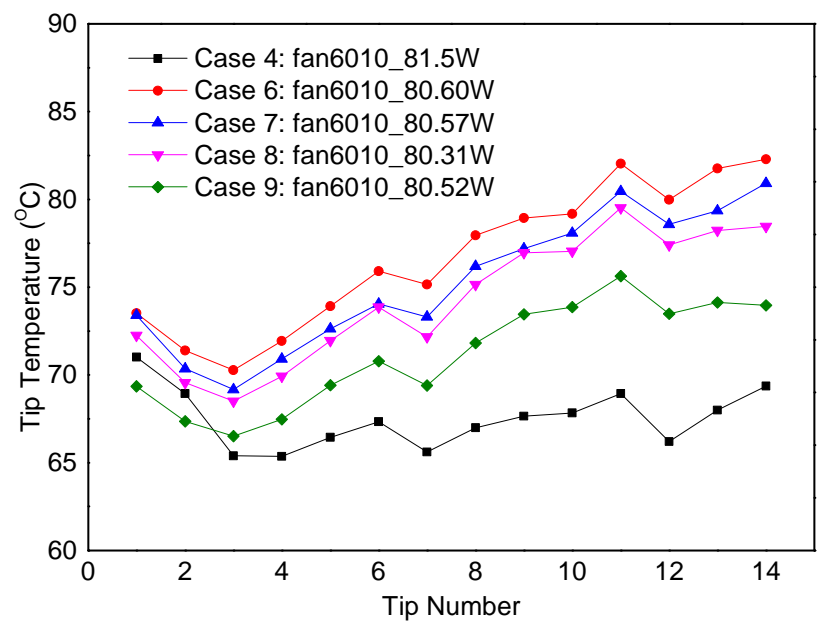

Fig. 16. Temperature estimated for each tip ends with different side-blowing cases using FAN6010 (Ambient temperature is off-set to $35^{\circ} \mathrm{C}$ )

Guided by the numerical results for the side-blowing method with guided walls, we conducted several experiments with different wall types. Similar experimental settings were conducted to evaluate the performance when a fan is installed at the side of the whole cell card. Cases 6 to 9 in Figure 15 show different guided wall configurations. Case 6 is the barely side-blowing case used as the reference to compare the performance of guided wall cases. Case 7 through case 9 show different wall types for side-blowing with guided walls. For case 7 , we used a flat plate along the bottom surface of the fan, and two side walls to avoid air leaks at the side part. In cases 8 and 9, we used an air duct to guide to air flow through the heatsinks. Figure 16 summarizes the experimental results of the temperature distribution for guided wall cases when the fan is set at the side of the cell card, compared to case 4 when the fan is set at the center underneath the cell card. For case 6, we can see that setting the fan at the side of the cell card without any guided wall would result in a relatively high average temperature (higher than $75{ }^{\circ} \mathrm{C}$ ) and maximum temperature (higher than $80^{\circ} \mathrm{C}$ ) which does not meet our requirements. For different guided wall cases, cases 7,8 and 9 show about $2{ }^{\circ} \mathrm{C}$ to $8{ }^{\circ} \mathrm{C}$ improvement. Case 9 shows the best heat transfer performance. For case 9 , the average temperature of all the heating fingers is about $71^{\circ} \mathrm{C}$, which makes it a potential method to meet the target temperature requirement with further optimization. 


\subsubsection{Performance of different types of Ingress Protection (IP) rated fan}

Although the fan installation position has a remarkable impact on the overall cooling performance, the optimization results also strongly depend on the performance of the fan itself. Two criteria should be taken into consideration when selecting the fans. First, due to assembly requirements, a fan with a frame size of $50 \mathrm{~mm} \times 50$ $\mathrm{mm}$ will better suit the size of the cell card. Second, the fan should sustain the harsh outdoor working environment. Therefore, we narrowed our target to waterproof and dust-proof fans. For these two reasons, manufacturers capable of providing the fans we need are quite limited. Our previously tested FAN6010 can provide the air flow up to 15.49 CFM while consuming $1.92 \mathrm{~W}$ of power. Thus, among all manufacturers which can provide IP rated fans with different working voltages, we selected seven different fans with power requirements no greater than that of FAN6010 which can provide similar air flow rates.

Meanwhile, to achieve the best performance of a specific fan, the mating between the heat sink plays a crucial role. Thus, we then used the seven different fans to numerically optimize the heatsink design corresponding to different fan curves. Our numerical optimization study also needs to consider the manufacturing constraints, i.e. the fin thickness should be no less than $1 \mathrm{~mm}$ and heatsink base thickness should be no more than $3 \mathrm{~mm}$. Based on seven potential IP rated fans under a maximum heat load of $84 \mathrm{~W}$ for both Designs I and II, results show that optimized fin numbers range from 13 to 16 . Due to machining capabilities we compromised and used a 12-fin heat sink design for the experimental tests.

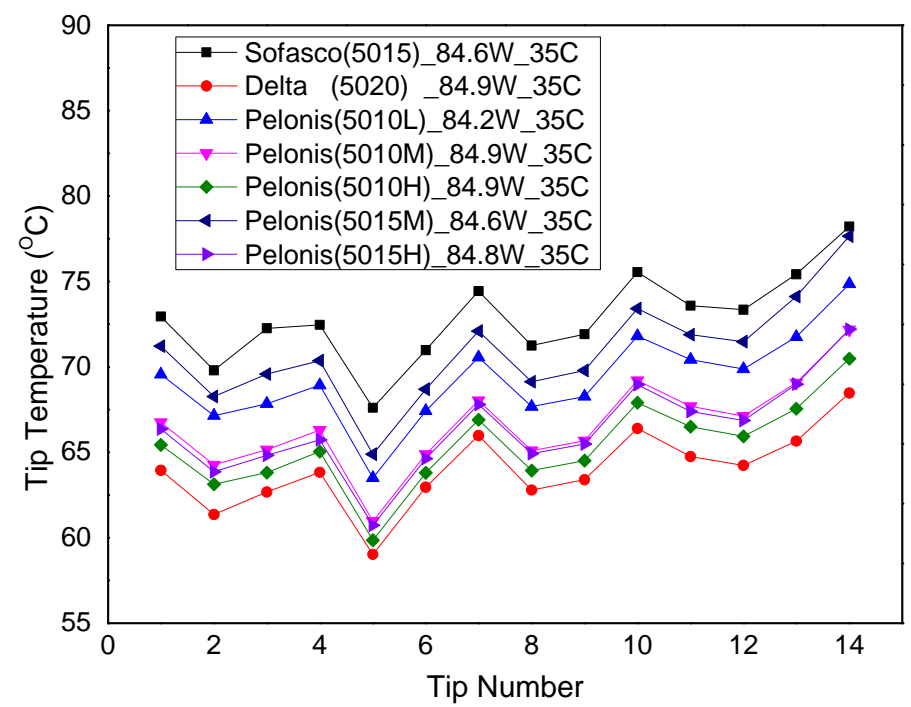

Fig. 17. Temperatures estimated for each tip end with different IP rated fans. (Ambient temperature is off-set to $\left.35^{\circ} \mathrm{C}\right)$

Figure 17 shows the experimental results of the average tip end temperatures with different types of fan and heatsink combinations. Detailed data can be found in Table 3. The results show that Delta5020 $(50 \mathrm{~mm} * 50 \mathrm{~mm} * 20$ $\mathrm{mm}$ ) shows the best cooling performance and can maintain an average temperature of $63.9^{\circ} \mathrm{C}$ when the ambient temperature is off-set to $35^{\circ} \mathrm{C}$. It can be expected that if the ambient is $45^{\circ} \mathrm{C}$, the Delta5020 fan can likely maintain the temperature below $75^{\circ} \mathrm{C}$. Pelonis $5010 \mathrm{H}, 5010 \mathrm{M}$ and $5015 \mathrm{H}$ show higher temperatures with the comparable or even higher power consumption. For Sofasco5015, Pelonis 5010L, and 5015M, although the power consumption is lower, the tip temperature is much higher than that of the Delta5020 fan.

To evaluate the performance for different fans, it is necessary to calculate the overall net gain. The offsets of the temperatures will provide an enhancement or deterioration to the PV cell efficiencies. From the characteristics of the PV cells used in our system, a $0.12 \%$ improvement in efficiency can be obtained via a $1{ }^{\circ} \mathrm{C}$ reduction in temperature. We can estimate the gain/loss per cell card with the following equation,

$$
\mathrm{Q}=\mathrm{Q}_{\text {total }} \times 0.12 \% \times\left(75^{\circ} \mathrm{C}-\mathrm{T}_{\text {cell. ave }}-\left(35^{\circ} \mathrm{C}-\mathrm{T}_{\text {monthly, ave }}\right)\right)
$$


where, $Q_{\text {total }}$ is the sum of the electricity output and waste heat for each cell card; $T_{\text {cell, ave }}$ is the average temperature of the $\mathrm{PV}$ cells under a $35{ }^{\circ} \mathrm{C}$ ambient, and $\mathrm{T}_{\text {monthly, ave }}$ is the monthly average high temperature in Tucson, AZ. Note that for the forced air cooling design the power consumption of the fan is subtracted from the total net gain.

Table 3

Experimental Results for different IP rated fans (Ambient temperature is off-set to $35^{\circ} \mathrm{C}$ ).

\begin{tabular}{cccc}
\hline Fan type & $\begin{array}{c}\text { Heat load } \\
(\mathbf{W})\end{array}$ & $\begin{array}{c}\text { Averaged tip } \\
\text { end temperature }\left({ }^{\circ} \mathrm{C}\right)\end{array}$ & $\begin{array}{c}\text { Power Consumption } \\
(\mathbf{W})\end{array}$ \\
\hline Delta5020 (IP55) & 84.6 & 63.9 & 1.92 \\
Sofasco5015 (IP55) & 84.9 & 72.8 & 1.80 \\
Pelonis 5010H (IP67) & 84.2 & 65.3 & 2.64 \\
Pelonis 5010M (IP67) & 84.9 & 66.6 & 1.92 \\
Pelonis 5010L (IP67) & 84.9 & 69.2 & 1.44 \\
Pelonis 5015H (IP67) & 84.6 & 66.3 & 1.92 \\
Pelonis 5015M (IP67) & 84.8 & 70.9 & 1.44 \\
\hline
\end{tabular}

\section{Table 4}

Average hourly net gain estimations for optimized fans/heatsinks per cell card based on monthly average temperatures when heat load is $84 \mathrm{~W}$.

\begin{tabular}{ccccc}
\hline Fan type & $\begin{array}{c}\text { Net gain for } \\
\text { Design I (W) }\end{array}$ & $\begin{array}{c}\text { Net gain for } \\
\text { Design II (W) }\end{array}$ & $\begin{array}{c}\text { Averaged tip end } \\
\text { temperature } \\
\left(\mathbf{3 5}{ }^{\circ} \mathrm{C}\right)\end{array}$ & $\begin{array}{c}\text { Averaged tip end } \\
\text { temperature } \\
\left(\mathbf{4 5}{ }^{\circ} \mathrm{C}\right)\end{array}$ \\
\hline Delta5020 (IP55) & 0.76 & 1.24 & $59.1^{\circ} \mathrm{C}$ & $69.1^{\circ} \mathrm{C}$ \\
Sofasco5015 (IP55) & 0.48 & 0.73 & $66.9^{\circ} \mathrm{C}$ & $76.9^{\circ} \mathrm{C}$ \\
Pelonis 5010H (IP67) & 0.45 & 0.63 & $63.5^{\circ} \mathrm{C}$ & $73.5^{\circ} \mathrm{C}$ \\
Pelonis 5010M (IP67) & 0.67 & 0.85 & $66.3^{\circ} \mathrm{C}$ & $76.3^{\circ} \mathrm{C}$ \\
Pelonis 5010L (IP67) & 0.69 & 0.84 & $65.6^{\circ} \mathrm{C}$ & $75.6^{\circ} \mathrm{C}$ \\
Pelonis 5015H (IP67) & 0.58 & 0.76 & $64.6^{\circ} \mathrm{C}$ & $74.6^{\circ} \mathrm{C}$ \\
Pelonis 5015M (IP67) & 0.40 & 0.65 & $70.4^{\circ} \mathrm{C}$ & $80.4^{\circ} \mathrm{C}$ \\
\hline
\end{tabular}

Based on the optimization results, the annual gain/loss was processed for seven fans, as listed in Table 4. The Delta5020 fan not only has the lowest temperature, but also the highest net gain compared with other fans. Therefore, Delta5020 is recommended for our design, in particular, if the ambient temperature is higher than $45^{\circ} \mathrm{C}$. When the Delta5020 fan is set at the center underneath the heat sink, it can maintain tip ends temperatures at about 
$64{ }^{\circ} \mathrm{C}$, while our numerical results for the Delta5020 fan show tip end temperatures of $59{ }^{\circ} \mathrm{C}$. As previously concluded, considering the thermal contact resistance, the maximum deviation between the model predictions and experimental measurements is about $5 \%$. Given Delta5020 as the potential fan, an optimization is processed to design the heatsink with constraints, which are decided from the spatial interference of the whole system and manufacturing limitations. Finally, an optimized 16-fin design, with the dimensions shown in Table 5, will be used.

\section{Table 5}

Heat sink optimization results for Delta5020 fan.

\begin{tabular}{ccc}
\hline Parameters fixed during the optimization & Range & Optimized result \\
\hline Fin number & $10-18$ & 16 \\
Heatsink height (mm) & $25-35$ & 35 \\
Fin thickness (mm) & $1-1.5$ & 1 \\
Heatsink base thickness (mm) & $2-10$ & 3 \\
\hline
\end{tabular}

\subsection{Comparison of passive cooling and active cooling design}

Although forced air cooling is capable of maintaining lower average temperatures than passive cooling, which means higher efficiency for the PV cells, the power consumption of the fans reduces the overall gain. Therefore, it is necessary to evaluate the net gain for both cooling methods. Two different split ratios of solar radiation are studied. Design I has a smaller solar radiation and corresponding heat load. In Design I, the maximum heat load is $64 \mathrm{~W}$. In Design II, the maximum head load is $84 \mathrm{~W}$. Average PV cell temperatures at different heat loads varying from $5 \mathrm{~W}$ to $84 \mathrm{~W}$ were collected. These data were used to estimate the annual performance of the forced air cooling method. The operating hours, heat load, and electricity output are based on the 20th day of each month. Those data are obtained at a constant operating temperature: $75^{\circ} \mathrm{C}$. Therefore, the offsets of the temperatures will provide an enhancement or deterioration in the PV cell efficiencies. For the forced air cooling, the fan power is subtracted from the total gain. Table 6 lists the average hourly gain of two cooling methods. It can be found that:

1. The Passive cooling option cannot meet the set-up goal; even though it has a larger gain than Delta5020 for Design I. As mentioned in the experimental results, passive cooling cannot meet the base goal when the heat load is larger than $50 \mathrm{~W}\left(13 \mathrm{~W} / \mathrm{cm}^{2}\right)$. Hence, this method will become more attractive when the heat load is relatively small.

2. Forced air cooling with fan Delta5020 can not only meet the set-up goal but also has the lowest average temperature. In particular, it can meet a more stringent goal: maintaining the temperature below $75^{\circ} \mathrm{C}$ when the ambient temperature is $45^{\circ} \mathrm{C}$ during some of the hottest days in Tucson, AZ.

\section{Table 6}

Average hourly net gain estimation of two cooling methods during a year (W/cell card) (Ambient temperature is offset to $35^{\circ} \mathrm{C}$ ).

Cooling method Design I: Design II:

Average temperature

when heat load is $84 \mathrm{~W}$

$\begin{array}{clll}\text { Forced air cooling with fan: Delta5020 (16 fins) } & 0.76 \mathrm{~W} & 1.24 \mathrm{~W} & \sim 60^{\circ} \mathrm{C} \\ \text { Passive cooling(double heat pipe with annular fins) } & 0.85 \mathrm{~W} & 0.03 \mathrm{~W} & >100^{\circ} \mathrm{C}\end{array}$




\subsection{Ongoing Onsite Demonstration and Testing}

Figure 18 displays the assembly in trough-level, which is schematically shown in Figures 1 (b) and (c). The assembly started from the attachment of heat sinks to the PV cell cards, followed by the fan brackets, IP-55 fans, and the power cord wiring for the fans (Figure 18). Thin Fresnel lenses were then attached on one side of the PV cell cards (not shown here). One stainless frame carries $12 \mathrm{PV}$ cell cards. Those cards settle at the premachined slots, share the same structural linkage and can rotate simultaneously. Seven stainless frames (assembly completed in June 2016, 84 PV cell card modules in total) will then be moved to a rental field in Tucson, Arizona, for a year-round test.

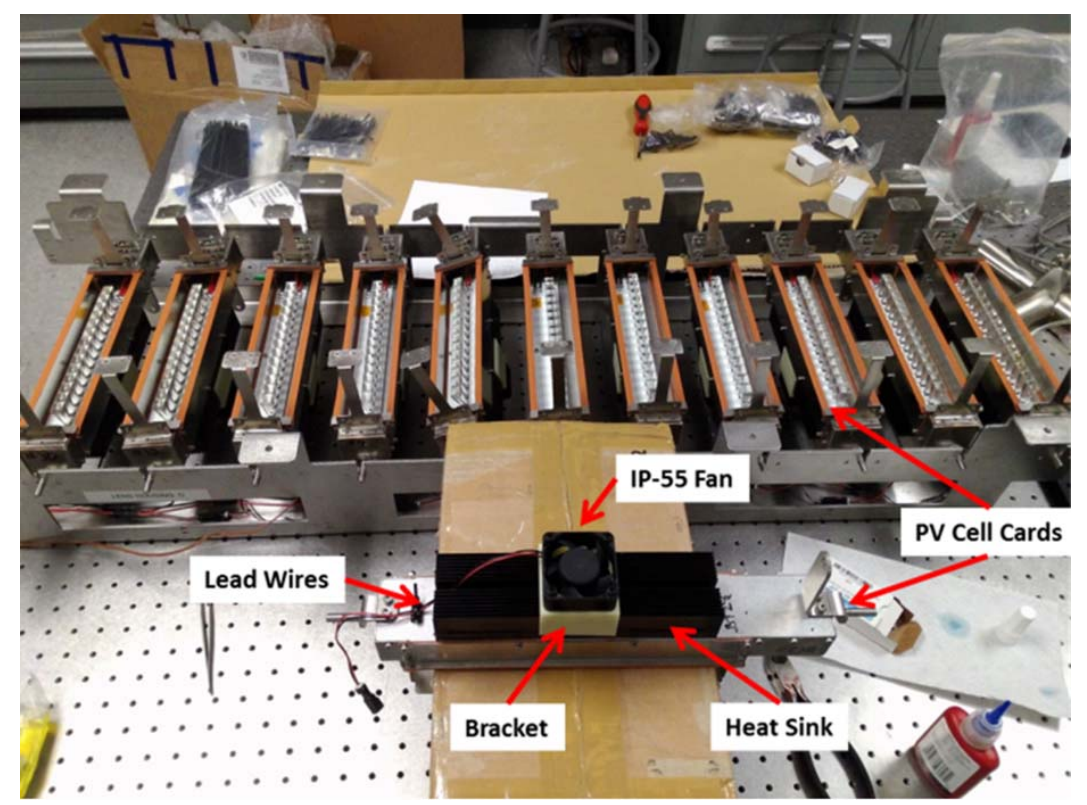

Fig 18. Photograph of the first stage assembly, before Fresnel lenses were installed

\section{Conclusions}

A practical cooling solution for a hybrid solar energy system, using dichroic mirrors to reflect light in the optimized band (for CPV) and transmit the remainder to the heat collector (for CSP), which combines the advantages of concentrated solar power technology and high performance concentrated photovoltaic cells together was introduced in this study. The greater concentration of solar radiation onto the CPV cells not only leads to higher performance but also generates larger waste heat, which makes the thermal management for the PV cell of greater importance. It is the first time for the potential cooling solutions proposed towards this novel and sophisticated hybrid solar energy system. The cooling design is challenging because: (1) the system is not only required to rotate daily to track the Sun, but also to be able to tilt at a specific angle to align with the latitude, and (2) the space allowed for rejecting waste heat underneath the trough is limited. In this work, comprehensive experimental and numerical study of both passive and active cooling methods for PV cell thermal management in a hybrid solar energy system were conducted.

For passive cooling, the heat transfer performance of different combinations of a single heat pipe or double heat pipe configuration with radial fins or annular fins were evaluated. Results show that the design with two heat pipes and two radial-fin heatsinks can bring most of the PV cells to the target temperature of $75^{\circ} \mathrm{C}$ or below under $43 \mathrm{~W}$ or lower heat load; while the design of two heat pipes with annular-fin can only handle the heat load below 50 $\mathrm{W}$. For the active cooling design, in order to find the most cost-effective way to meet our heat rejection requirement, we have tried different fan and heatsink combinations to dissipate the waste heat. A high IP rated fan (Delta5020) with relatively low power consumption was selected for on-site use, and an optimized heatsink was proposed accordingly. Results show that the final forced air cooling design with the Delta5020 fan and an optimized heatsink can maintain the lowest average temperature of the PV cells; in particular, it can even meet our optimal goal of maintaining the temperature below $75^{\circ} \mathrm{C}$ when the ambient temperature is $45^{\circ} \mathrm{C}$. 
In summary, it is clear that the active cooling method is much more competitive than the passive cooling method for high heat flux applications. Based on the overall performance, while also taking into consideration both the temperature control results and system cost, the active cooling design was chosen in our system for a maximum heat load of $84 \mathrm{~W}\left(21.8 \mathrm{~W} / \mathrm{cm}^{2}\right)$ due to its lower cost, lower CPV temperature, and higher net energy efficiency gain. It is also demonstrated that passive cooling will be more attractive when the heat dissipation requirement is less than $50 \mathrm{~W}\left(13.0 \mathrm{~W} / \mathrm{cm}^{2}\right)$.

\section{Acknowledgment}

The authors gratefully acknowledge the support of ARPA-E under Grant No. SLA-UM DE-AR0000465, and Zhaoqing Ke for a helpful discussion about the numerical study.

\section{References}

[1] A.A.B. Baloch, H.M.S. Bahaidarah, P. Gandhidasan, F.A. Al-Sulaiman, Experimental and numerical performance analysis of a converging channel heat exchanger for PV cooling, Energy Conversion and Management, 103 (2015) $14-27$.

[2] A. Kumar, P. Baredar, U. Qureshi, Historical and recent development of photovoltaic thermal (PVT) technologies, Renewable \& Sustainable Energy Reviews, 42 (2015) 1428-1436.

[3] S.R. Reddy, M.A. Ebadian, C.X. Lin, A review of PV-T systems: Thermal management and efficiency with single phase cooling, International Journal of Heat and Mass Transfer, 91 (2015) 861-871.

[4] H.G. Teo, P.S. Lee, M.N.A. Hawlader, An active cooling system for photovoltaic modules, Applied Energy, 90 (2012) 309-315.

[5] J. Ji, Y.F. Wang, T.T. Chow, H.F. Chen, G. Pei, A Jet Impingement/Channel Receiver for Cooling Densely Packed Photovoltaic Cells under a Paraboloidal Dish Solar Concentrator, Heat Transfer Research, 43 (2012) 767778.

[6] A. Royne, C.J. Dey, D.R. Mills, Cooling of photovoltaic cells under concentrated illumination: a critical review, Solar Energy Materials and Solar Cells, 86 (2005) 451-483.

[7] W.G. Anderson, P.M. Dussinger, D.B. Sarraf, S. Tamanna, Heat Pipe Cooling of Concentrating Photovoltaic Cells, Pvsc: 2008 33rd Ieee Photovoltaic Specialists Conference, Vols 1-4, (2008) 905-910.

[8] K. Araki, H. Uozumi, M. Yamaguchi, A simple-passive cooling structure and its heat analysis for $500 \mathrm{X}$ concentrator PV module, Conference Record of the Twenty-Ninth Ieee Photovoltaic Specialists Conference 2002, (2002) 1568-1571.

[9] M. Theristis, T.S. O'Donovan, Electrical-thermal analysis of III-V triple-junction solar cells under variable spectra and ambient temperatures, Solar Energy, 118 (2015) 533-546.

[10] N. Arcuri, F. Reda, M. De Simone, Energy and thermo-fluid-dynamics evaluations of photovoltaic panels cooled by water and air, Solar Energy, 105 (2014) 147-156.

[11] B. Du, Y.M. Zhang, L.G. Sun, Experimental evaluation of solar cells in concentrating solar collectors with heat extraction by forced air flow, Proceedings of Ises Solar World Congress 2007: Solar Energy and Human Settlement, Vols I-V, (2007) 1575-1579.

[12] J.K. Tonui, Y. Tripanagnostopoulos, Air-cooled PV/T solar collectors with low cost performance improvements, Solar Energy, 81 (2007) 498-511.

[13] L.L. Si, Q.Z. Zhu, L.J. Mu, Q.F. Li, J.X. Ren, B.S. Xu, J. Jin, An Experimental Study of Air Cooling for Solar Cells in Building Applications, 6th International Symposium of Asia Institute of Urban Environment: Energy Conservation and Carbon Off in Asia City, (2009) 18-22.

[14] Y. Tripanagnostopoulos, P. Themelis, Natural Flow Air Cooled Photovoltaics, 7th International Conference of the Balkan Physical Union Vols 1 and 2, 1203 (2009) 1013-1018.

[15] K.K. Chong, W.C. Tan, Study of automotive radiator cooling system for dense-array concentration photovoltaic system, Solar Energy, 86 (2012) 2632-2643.

[16] J. Barrau, A. Perona, A. Dollet, J. Rosell, Outdoor test of a hybrid jet impingement/micro-channel cooling device for densely packed concentrated photovoltaic cells, Solar Energy, 107 (2014) 113-121.

[17] D. Montorfano, A. Gaetano, M.C. Barbato, G. Ambrosetti, A. Pedretti, CPV Cells Cooling System Based On Submerged Jet Impingement: CFD Modeling And Experimental Validation, 10th International Conference on Concentrator Photovoltaic Systems (Cpv-10), 1616 (2014) 135-139.

[18] A. Royne, C.J. Dey, Design of a jet impingement cooling device for densely packed PV cells under high concentration, Solar Energy, 81 (2007) 1014-1024. 
[19] J. Barrau, J. Rose, M. Ibanez, Design Of A Hybrid Jet Impingement/Microchannel Cooling Device For Densely Packed PV Cells Under High Concentration, 6th International Conference on Concentrating Photovoltaic Systems (Cpv-6), 1277 (2010) 74-77.

[20] T.J. Zhang, E.N. Wang, Design of a Microscale Organic Rankine Cycle for High-Concentration Photovoltaics Waste Thermal Power Generation, 2012 13th Ieee Intersociety Conference on Thermal and Thermomechanical Phenomena in Electronic Systems (Itherm), (2012) 993-1002.

[21] X.Q. Xu, M.M. Meyers, B.G. Sammakia, B.T. Murray, C. Chen, Performance and Reliability Analysis of Hybrid Concentrating Photovoltaic/Thermal Collectors With Tree-Shaped Channel Nets' Cooling System, Ieee Transactions on Components Packaging and Manufacturing Technology, 3 (2013) 967-977.

[22] K.J. Yang, C.C. Zuo, A novel multi-layer manifold microchannel cooling system for concentrating photovoltaic cells, Energy Conversion and Management, 89 (2015) 214-221.

[23] T. van Kessel, A. Abduljabar, H. Khonkar, N. Moumen, R. Sandstrom, Y. Al-Saaedi, Y. Martin, S. Guha, Concentrator Photovoltaic Reliability Testing at Extreme Concentrations up to 2000 Suns, 2009 34th Ieee Photovoltaic Specialists Conference, Vols 1-3, (2009) 1850-1853.

[24] A.H. Alami, Synthetic clay as an alternative backing material for passive temperature control of photovoltaic cells, Energy, (2015).

[25] L. Micheli, N. Sarmah, X.C. Luo, K.S. Reddy, T.K. Mallick, Opportunities and challenges in micro- and nanotechnologies for concentrating photovoltaic cooling: A review, Renewable \& Sustainable Energy Reviews, 20 (2013) 595-610.

[26] X.Y. Han, Y.P. Wang, L. Zhu, The performance and long-term stability of silicon concentrator solar cells immersed in dielectric liquids, Energy Conversion and Management, 66 (2013) 189-198.

[27] X.Y. Han, Q. Wang, J. Zheng, J. Qu, Thermal Analysis of Direct Liquid-Immersed Solar Receiver for High Concentrating Photovoltaic System, International Journal of Photoenergy, (2015).

[28] H.A. Hussien, A.H. Numan, A.R. Abdulmunem, Improving of the photovoltaic/thermal system performance using water cooling technique, 9th Curtin University of Technology Science and Engineering International Conference 2014 (Cutse2014), 78 (2015).

[29] M. Habiballahi, M. Ameri, S.H. Mansouri, Efficiency Improvement of Photovoltaic Water Pumping Systems by Means of Water Flow Beneath Photovoltaic Cells Surface, Journal of Solar Energy Engineering-Transactions of the Asme, 137 (2015).

[30] G.Q. Li, G. Pei, M. Yang, J. Ji, Experiment Investigation on Electrical and Thermal Performances of a Semitransparent Photovoltaic/Thermal System with Water Cooling, International Journal of Photoenergy, (2014).

[31] M.T. Kuo, W.Y. Lo, A Combination of Concentrator Photovoltaics and Water Cooling System to Improve Solar Energy Utilization, Ieee Transactions on Industry Applications, 50 (2014) 2818-2827.

[32] H.M. Bahaidarah, S. Rehman, P. Gandhidasan, B. Tanweer, Experimental Evaluation of the Performance of a Photovoltaic Panel with Water Cooling, 2013 Ieee 39th Photovoltaic Specialists Conference (Pvsc), (2013) 29872991.

[33] S. Odeh, M. Behnia, Improving Photovoltaic Module Efficiency Using Water Cooling, Heat Transfer Engineering, 30 (2009) 499-505.

[34] M. Abdolzadeh, M. Ameri, Improving the effectiveness of a photovoltaic water pump system by applying water flow over photovoltaic cells, Proceedings of Ises Solar World Congress 2007: Solar Energy and Human Settlement, Vols I-V, (2007) 1430-1434.

[35] A. Aldossary, S. Mahmoud, R. Al-Dadah, Technical feasibility study of passive and active cooling for concentrator PV in harsh environment, Applied Thermal Engineering, 100 (2016) 490-500.

[36] R. J. Moffat. Uncertainty Analysis, Electronics Cooling Magazine, May, 1999.

[37] R. J.Moffat, Contributions to the theory of single-sample uncertainty analysis. ASME, Transactions, Journal of Fluids Engineering, 104(1982) 250-258.

[38] J. Rice, A. Fagh, Analysis of screen wick heat pipes, including capillary dry-out limitations, Journal of Thermophysics and Heat Transfer, 21 (2007) 475-486. 